\title{
Leadership in Islamic Education Institution
}

\author{
Supriadi \\ Department of Islamic Studies, STAIN Syech Djamil Jambek Bukittinggi, Indonesia \\ E-mail: supriadi@yahoo.com \\ DOI: http://dx. doi.org/10.15548/jt.v21i3.104
}

\begin{abstract}
Education institution may not be separated by social system. It can be formal and informal education. A formal education institution such as school, Islamic school or Islamic boarding school is in social environment and bringing a basic value and law from its institution. Meanwhile, Islamic education institution is believed as tool to reach the aim of education. The aim of education is hard to reach if there is no leadership in it.
\end{abstract}

Keywords: Leadership, Islamic institution, education institution

\section{INTRODUCTION}

Basically, a leadership is the core of management process in administrative. This activities include managing system which is well known as organization. In fact, the most important thing is still leadership.In other words, a leadership can be described as the ability to influence people to follow something which is approved together, leadership enhances all the components to get involved in order to reach some goals. All the components is at least a leader, institution, regulation, and members as basic components of it.

Islamic education institution in short can be a simple organization which is transferring ideas and assessment to the students. It has a long process to reach, so it needs a good leadership to make it easier.

A leadership in institution is about to create something by planning, coordinating, managing, and assessing all the activities which are approved. It drives the institution brighter, effective, and efficient.

\section{DEFINITION OF LEADERSHIP}

A leadership can be defined in many ways. The writer wants to give a brief description of it by showing what some experts has defined. Dirawat (1988:8) defined a leadership as an ability and influencing process, educating, coordinating and driving the people in order to develop their knowledge by educating them, in order to reach the aim more efficient and effective. Then, Abu Ahmadi (1991:88) said so. He stated: "influencing process, directing, and coordinating the individual of organization in order to reach the goal which is already set. U Husna Asmara (1985:18) defined a leadership as :All activities to influence person in educational circumstance in certain moment in order they get through cooperation, work with responsibility and sincerity to achieve the goal of education which is determined.

From the above definition, it can be concluded that leadership is the process to move, influence, motivate, and directthe people in education organization to achieve the purpose which is maintained before. Therefore, the leadership is a wide concept where it relates to objective quality which is useful and influential to the education institution and society. The emphasis isn't in the best way to achieve that objective but give priority to normative quality that is achieved beyond its concern with the formal education institution mission (school. Madrasah, boarding school).

FORMAL AND INFORMAL LEADERSHIP 
In formal education institution (school, madrasah, boarding school) There are two kinds leadership, formal and informal leadership. It is the same case like Ahmad Rohani and Abu Ahmadi (1991: 90-91) mentioned that there are a formal leadership which implied in certain position and also there is a leadership because society admit the capability of people who can run the leadership. The visible distinction between formal and informal leadership is the formal leadership in implementation always on basis or formal rules where it has unlimited wide range. The informal leadership has unlimited formal wide range because this leadership is based on recognition and trust of society.

Hadari Nawawi (1998: 77) explained that: "In world education circumstance, there are many cooperation efforts in some people to achieve the certain goal which is committed altogether. One of the cooperation is established as the intentional formal education institution, well planned, and systematic. The leader of this institution is usually appointed by higher institution with position as a chief. Besides, there is a leader who is appointed by certain person in that education institution then by the higher one and it $s$ called formal leader. In some case, if the chief is not capable as a leader, there is one person that is considered by other people in the institution circumstance as the capable leader. This leader is called informal leader."

From the expalanation above, it can be understood that formal leader can be formally influenced toward to his followers because his position or the authority that is given formally by the institution. Formal leader in his leadership implementation makes plan function, organization arrangement, and work control toward to his followers. On the other hand, informal leader gives his influence not by his position or authority which he got from organization. The influence is from his capability that is needed by the member of group.

The two kinds of leaders have the same purpose, for example in school are the principal formal leader toward his authority and position. He gets the order from government in the name of school to use his influence to the teachers, employees,etc. but if this order is taken off, the formal influence can give the effects no more for the members.

The principal can not only become a formal leader but also as an informal leader. He he can be the formal leader because of his experience. From this quality, he can use it to influence as a leader. Having said that, it can be seen that a formal leader can be as informal leader at the same time if he has other qualities that can make him influential in that institution. In Islamic education institution, two kinds of these leaders must be united into Islamic leadership where he has formal order but also is demanded as model in every part of life.

The individual leadership achievement is influenced by the hopes of the member of group which he led. Those hopes not only relate to his leadership influence but also his effectivity. Efficiency and stability in work group. The basis, influence, and the process of hopes related to the teaching program should be analyzed in order to help the leader overcome the education challenges this time.

The term of role in this case is used to show that the man behind the desk is the man who responsible in cetain education institution related to the islamic education, so who more responsible to that education process. In this case, the author want to explain the responsibility of education in forlam education institution. Having said that, the responsibility is about who responsible toward to the result of education implementation.

According to Amir Daien Indrakusuma (1999 : 137) the people who responsible to the result of education is on children education, the 
responsible of education is in the teacher. They as:

- Senior High School, the students have a big responsibility for education that they look for.

- University, the object of education is students. They are having arrived at maturity or assumed as adult.

From this description, it can be concluded that good or bad the institution based on the personals in it. The result of education is influenced by the whole process in it.

In educational process or the process of educating in same institution, every person is developing, it can be defined broadly. It is not only about getting mature but it is also enriching his/her personality, knowledge and other competences. This process is determined by some factors. They can be internal or external. One of them is the leadership of a leader in that institution. In other way, a leader takes a big responsibility in giving direction of institution, he/she drives the institution to good or bad way. The leader determines the process. In this case, the leader is also educator, because educating is about giving a good direction.

From some description above, it can be concluded that the relationship between Islamic education and leadership is very close. However, in any condition, an educator is always a leader with good leadership in order to reach the aim of its Islamic education.

\section{THE ROLE AND AND PRINCIPAL OF LEADERSHIP ON ISLAMIC INSTITU- TION}

\section{The Role of Leader on Islamic institution}

As mentioned above, the role of a leader can be seen by what the education experts say. Hadari Nawawi (1998:83) stated the roles of a leader as follow:

1). Developing and transferring the freedom of thinking and giving opinion, it can be individual or group in order to collect the data or material for the members in making a decision.

2). Creating a good working environment effectively by giving reward and competence for all members so that they can respect the people around them.

4). Enhancing and creating a forum for sharing ideas, making a sense of responsibility of all members in doing their tasks in order to reach the goal.

5). Helping in troubleshooting the problem, individually or group by giving a good direction so the problem will be clear.

From explanation above, it can be seen that the responsibility of leader is hard. Besides being creative, a leader should have a lot of ideas and always be a good model for his/her members.

Hendiyat Soetopo and Wasti Soemanto (1988:4-6) classified the functions of education into two as: the function about the aim of education and the function about creating a good environment. The function about the aim of education can be categorized into:1). Thinking, formulating with detail the aim of the group so all members can work together as well; 2). Giving support to all members of group and describing the situation; 3). To help the member of group in collecting the important data in order to construct the right considerations; 4). To use the speciality and the capability from the members of group; 5). To motivate every member to produce role and thinking and select the good and useful thinking; 6). to give trust and responsibility to the member in implementing the task based on their own abilities. Meanwhile, the function which related to creating comfortable work environment can be devided into: 1) To keep and maintain the sincerity of cooperation in group to achieve the goal; 2). To keep the awareness to every member of group in order they can still happy and on fire in working together; and 3). To 
provide the comfortable work place whether in he room, facility, or circumstance.

The general description of education leadership function which is described above, if we related all of that to the islamic education goal is the effort which is directed to construct Islamic the personality or certain efforts by follwing islamic way and decide every steps based on Islam in responsible manner.

Leadership in islamic education institution is the process to maintain the value of islam by giving the influence, motivation, and to pull out alll the potention in order to eachieve the goal of islamic education. In other words, leadership in islamic education institution must in range of Islam rules. That is why a educator can be functioned as the leader of Islam must implement his function as educator but at the same time as the responsible leader toward to the achievement of education programs that on the track in islamic principals.

Based on the functions that is explained above, it can be understood that the leader role in education institution have multi roles beside as the educator. Hadari Nawawi (1995 : 74-83) categorizes the role of leader into six types. In general understanding, the role is ffective if it is implmented on education leadership. The roles are Instructive, Consultative, Participative, Delegation, Control, and Model.

1). Instructive Role

In this role, it can be seen there is one direction of communication but must be communicative because it needs all aspects in institution particularly the aspect of the people who are commanded. In the implementation, the leader must able to determine what, how, if, and where certain order is instructed. The role of the people who are odered are to do what is decided by leader.
2. Consultative Role

There is two direction of communication that is implemented in interaction between leader and the people under command. The problem is the level of effectivity and and intensity is still depends on leader.

3). Participative Role

The participation is discussion and implementation as the decision which has determined. The role of leader in implementing the activites is to activate the member in order to give them chance to communicate effectively in leadership.

4). Delegation Role

Every leader is not possible to work alone to achieve the task of organization. The leader must share the task to some people who he can trust. Delegation of leadership must based on the proficiency.

5. Control Role

To control the people under command in order they cannot violate the rule by supervising and directing so the purpose can be achieved optimally.

6. Model Role

A leader should become the best model (uswatun hasanah) for the peaole he led. A good character is the highest level of moral. Every leader should become the model in the way of life, habit, attitude, and everthing that is done to the people that he led.

\section{THE PRINCIPALS OF LEADERSHIP IN ISLAMIC EDUCATION INSTITUTION.}

In implementation of leadership task in education institution, it must be able to run it based on its function. The implementation of this leader funtion has an intense relationhip to the personality of the leader. The personality of 
leader that appropriate to become as model is the character of deep thinking, attitude and behaviour. It reflects the contains of Al Qur'an. That leader can be found In Rasulullah personality, Allah said in AL Ahzab of AlQuran letter verse 21:

Truly, there was in Muhammad a very good model for you, for those who hope the God's mercy and the arrival of judgment day, and he always rosary of god (Al-Ahzab:21).

From the verse above, it is understood that prophet is a noble person as a model (example) and guide in various aspects of life. Imam munawwir (1999 : 181) said : "rarely a leader who give a very good model (example) as Rasulullah does. What he leads is agree with fact, between confession and behavior, no one else like him.."

Prophet reflected who he is, the glory of his character, friendship, patience, bravery, particularly his mirth and sincerity to stay in truth, love and amorousness to his ummah, tolerance and heroism in comforting the adversaries. Imam munawwir (1999: 195-196) said: the principle social characters of prophet are as sincere and philanthropist, good interaction, humble and forgiving, wise in leadership, the prime model (example) of leadership, and firm belief.

Prophet Muhammad has given big change for 23 years his prophet time, he reaches the big change because of the firm faith, grandeur character, glorious behavior, he leads all the mankind to the truth, educates them, rises united and free society with all these goodness. This is a model and example to all mankind, the leadership of Rasulullah includes every aspect of life, in this discussion, author explained that prophet Muhammad educates his ummah to love and respect each other, old and young, a hadith from Annas bin Malik shown the amorousness of Rasulullah:

"Quoted from Annas bin Malik, he said Rasulullah ,peace be upon him: one day my sun is born, a baby boy, and I name him with your father name Ibrahim, then I sent him to Ummu Syaif, wife of an iron smith Abi Saif, Rasulullah visits him and I follow, when we arrived, he was flowing the fire in his workshop till the home is covered with smoke, I told Abu Saif, would you stop working for awhile, Rasulullah is here, then he stops, Rasulullah asks about baby and put to his lap, then what is the utterance of rasulullah.? Annas ask, "I saw the baby willingly of the illness, comfortable in rasulullah's lab". Then the tears are falling down and rasulullah cries. He said "the tear may be flown, heart may be distressed, but we can't speak except what are blessed by Allah, oh Ibrahim, we are really sad of you". (narrated by Muslim)."

Another hadith explain that:

"Quoted from Abu Hurairah, he said: " aqra' the son of habis saw rasulullah kissed his grandchild hasan, 'ara' said: I have ten children, but I kissed none of them, rasulullah said: god will not bless the one who aren't charitable". (narrated by muslim)."

This is a glance of knowledge that rasulullah educate to his ummah in order to love each other begin from self and family and apply in society. We can follow a lot of good example of rasulullah as long as his life time, one of his wife said rasulullah is like walking Al Quran, Mahmud Syalabi (1997:50) said: rasulullah is a firm believer in spite of guaranteed into heaven, but it will not subtract his obedience to the god, moreover the story told that rasulullah does a long night worships till he swollen his leg.

Syaikh shafioyyur rahman Al Mubarakfury (1997:247) explain in other times: when Muslims work together to build nabawi mosque, in building it up rasulullah joins to 
remove the stones, in family life rasulullah was pleasantly patches his slipper, sews clothes, finishes the work by his self, washes the clothes, milked, take care of necessity, from this explanation we can conclude that rasulullah does not intend to be a king or emperor who always distinguish between his members and ummah, he pleasantly gets along people.

Another leadership principle of rasulullah is making dialog and discussing to figure out the problems, it is rarely realized in other leadership in his period, prophet Muhammad carry out discussion and appreciate sincerely the result, although different from his sight, Mahmud Syalabi explain (1997:13-25) as follow:

"in that time the troops of enemy leave for attacking masinah, at night rasulullah divine the massage from his dream, then he gathers his companion, he explain the situation that he faced and told the dream, he said at last: what is your opinion? Rasulullah opine that it is better Muslims against the enemy in the city, Abdullah bin ubai strengthen with his argument and enthusiasm, rasulullah said: we wait for other arguments".

Then, come the man who are not stay in badar war, with the enthusiasm spirit they demand to against the enemy out of medina, they wanted to be syahid, then Hamzah, Sa'ad bin Ubadah, nu'man dan other friends from 'Aus dan Khazraj said: do not you worry if the Quraish assumed we are afraid of them? That will make them braver in doing ravage". Then the ansars be in agreement, with the logical arguments, after recognizing many troops agree to against the enemy out of medina, it is decided to face the enemy out of medina, even some regret of it, it need to be done as a result of a discussion".

From the explanation above, it is understood that rasulullah build a discussion with the companion to reach the agreement, even there are some incompatibles, characters and attitudes of these good models (example) of rasullullah is what determine the success of the leadership its self, we can conclude that rasulullah's leadership is the reflection of a great personality and good model (example). Some principles of his leadership are: a great faith, wise, good interaction, efficiency and effectiveness of work method, educate the leadership, respect each other, flexible and adaptive, and glorious love. The leadership principles as mention above should be applied to the Islamic knowledge institution to reach the success of the leadership in the knowledge institution.

\section{FACTORS THAT INFLUENCED THE SUCCESS OF LEADER}

Leadership is the dynamic situation that comes from various factors of interactions, all these factors enable to reach the coherent movement, objective and systematic to achieve the aspiration, success and failure is balanced from the ability to build a good interaction between various related factors of the leadership, not only the external factors of the institution but also internal factors

According to U. Husna Asmara (1985:20) Factors that related to the success and failure of the leadership are divided into two factors:

1) Internal All the activities that related to the leadership, these activities take place in the organization itself, which consist of aim and goal of the organization, planning, arrangement of work and deciding of decision. Organize and employee development, human relation, controlling, evaluating and supervising

2) External

All the external activities that control the movement and development of leadership, which related to the situation, politic, economy, social culture and collaboration of society and other organizations. 
Meanwhile, Hendiyat Soetopo and Wasti Soemanto (1988: 16-18) divided into 6 main factors:

1) The legal factor that influenced the leadership

2) Social economy condition and knowledge concepts as the influential

- Social economy condition that enable to provide the sources and knowledge facilities

- Society Leadership concept of knowledge aim and common society

3) Reality and school feature

4) Personality of knowledge leadership and training

5) The transforms that occur along knowledge theory

6) Dean personality training

From the explanation above, basically, internal and external factors which influence leadership can be classified into supporting and barricade factor of the success leadership.

A management expert, Bernard M. Bass, as quoted by Agustiar Syah Nur (1998: 4-5), distinguishes the success and effective leadership, in short, it is said that the success of a leadership is relative, the success leadership is categorized into two categories, first, success leadership but is not affective, second, success and affective leadership. It is also said that success leadership is not affective if the members and employee duty is done by position power that reflected from an authoritative leadership, compulsive, and intimidation with a strong supervision. Main orientation of leader is "output" without consider the process. Whereas, success and affective leadership always consider the values in realization the leadership, turn over, the members and employee do the duty sincerely, and responsible to the duty, furthermore, it is said that success leader but is not affective will not stay longer because commonly only to accomplish the aim and purpose of the organization or the individual leader purpose, meanwhile, an effective leadership will continue to exist because of the comfortable atmosphere of the organization in result it increases the affectivity and quality of the work.

\section{CONCLUSION}

It can be concluded that a success and affective leadership give priority to work quality and quantity by considering the values in its process, while the leadership which seemed to be success in quantity, but basically is not success in quality because it does not prioritize the democracy value of his leadership. A leader is supposed to develop both individual and common quality in his leadership, the mastery of various disciplines knowledge, in this discussion, the author viewed from the leader internal factor (personality of a leader), a capable personality physically or mentally is a wished person, with this potential the leader able to manage optimally in order to reach the success of leadership, however, in developing self potential, there are some barriers in assembling it.

The success of a leader as commonly know is measured from realizing the productivity and affectivity of the duties, it is hard to make sure the success of a leadership appropriately because it is linked with various aspects which include technical, managerial administrative, social and humanity, but the indicator that uses in measuring the success and failure at least consist of some theory:

a. Quality increase / the value of an institution materially and spiritually

b. Administration system solid and management affective

c. Activity increase and human creativity

This success is related to the personality of the leader, besides the external factor that influences it. However, there are some barriers in developing personality of a leader, this is caused by:

1. The Unable of self manage, unable to develop the potential, power and skill. 
2. The fading of personality value, unclear personality value, inappropriate value of work, situation and condition

3. Unclear personality purpose, there is no personal ambition and certain work life,

4. Small-minded self development, less of attitudes, unable to come up and confront new challenge and chance

5. Unable to soft the problem in deciding decision

6. Low creativity, unable to create new idea

7. Low authority, unable to get new partner to have assist in solving the problem

8. Low ability of managerial such as motivation, interpersonal communication, human relation, negotiation and supervision

9. Ability to train and manage, unable to give high contribution

The confuse of the problems above takes a great control in successes a leader in leadership process, self development on leader is really necessary, the technique that use is the affective technique, in this discussion the author mention only five self development techniques which author believe is very affective, those are:

1. The ability of self manage

2. Clear personality value

3. Develop self ambition

4. Create a developing personal

5. Manage the group

if it is noticed accurately every problems that need high creativity and activity, it will became as habitual trough diligent, and systematic life. If we do "self-ported" self evaluation honestly, steps and day by day, we are as a new man each day, with new performance, that what we call self development.

\section{REFERENCES}

Asmara, U.H. (1985). Pengantar Kepemimpinan Pendidikan. Jakarta: Ghalia Indonesia Press.

Al-Mubarrakfury, S. S. R. (1997), Syirah Nabawiyah. Jakarta: Pustaka Al-Kautsar.

Daud, M. (1996), Terjemahan Hadist Sahih Muslim. Jakarta: Wijaya.

Dirawat, W. S. \& Soetopo, H. (1988), Kepemimpinan dan Supervise Pendidikan. Jakarta: Bumi Aksara Press.

Indra, K. \& Dien, A. (1999), Pengantar Ilmu Pendidikan. Surabaya: Usaha Nasional.

Munawwir, I. (1999), Asas - asas Kepemimpinan dalam Islam. Surabaya: Usaha Nasional.

Nawawi, H. (1998), Administrasi Pendidikan. Jakarta: Haji Masagung.

------ (1995), kepemimpinan yang Efektif. Yogyakarta: Gajah Mada University Press.

Rohani, A. H.M \& Ahmadi, A. (1991), Pedoman Penyelenggaraan Administrasi Pendidkan. Jakarta: Bumi Aksara.

Soetopo, H. \& Soemanto, W. (1988), Kepemimpinan dan Supervisi Pendidikan. Jakarta: Bina Aksara.

Syah Nur, A. (1988). Performasi dan Kredibilitas Pimpinan Lebih Utama dari Kompetensi Manajerial, IAIN, Faktar. Jakarta: Bina Aksara.

Syalabi, M. (1997). Kepribadian Rasulullah. Solo: Pustaka Mantiq. 